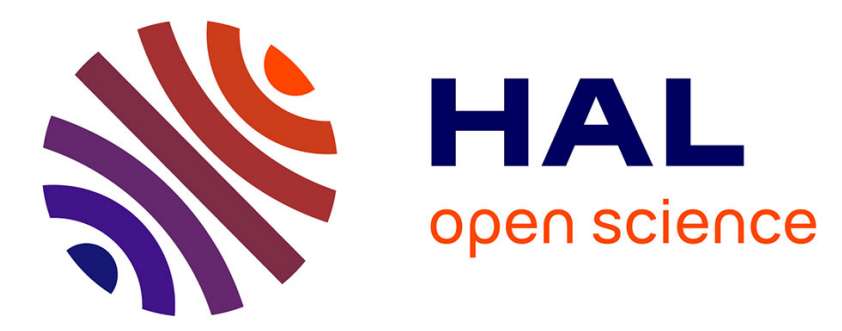

\title{
A comparative study of edetate calcium disodium and dimercaptosuccinic acid in the treatment of lead poisoning in adults
}

Kirushanthi Sakthithasan, Pierre Lévy, Joel Poupon, Robert Garnier

\section{- To cite this version:}

Kirushanthi Sakthithasan, Pierre Lévy, Joel Poupon, Robert Garnier. A comparative study of edetate calcium disodium and dimercaptosuccinic acid in the treatment of lead poisoning in adults. Clinical Toxicology, 2018, 56 (11), pp.1143-1149. 10.1080/15563650.2018.1478424 . hal-01979973

\section{HAL Id: hal-01979973 \\ https: / hal.sorbonne-universite.fr/hal-01979973}

Submitted on 14 Jan 2019

HAL is a multi-disciplinary open access archive for the deposit and dissemination of scientific research documents, whether they are published or not. The documents may come from teaching and research institutions in France or abroad, or from public or private research centers.
L'archive ouverte pluridisciplinaire HAL, est destinée au dépôt et à la diffusion de documents scientifiques de niveau recherche, publiés ou non, émanant des établissements d'enseignement et de recherche français ou étrangers, des laboratoires publics ou privés. 


\title{
A comparative study of edetate calcium disodium and dimercaptosuccinic acid in the treatment of lead poisoning in adults
}

\author{
Kirushanthi Sakthithasan ${ }^{a}$, Pierre Lévy ${ }^{b}$, Joël Poupon ${ }^{c}$ and Robert Garnier ${ }^{a}$ \\ ${ }^{a}$ Department of Environmental and Occupational Health, Fernand Widal Hospital, APHP, Paris, France; ${ }^{b}$ Department of Public Health, Tenon \\ Hospital, APHP, Sorbonne University and INSERM, UMR-S 1136 (EPAR Team), Paris, France; 'Toxicology Laboratory, Lariboisière Hospital, \\ APHP, Paris, France
}

ABSTRACT

Background: We evaluated the efficacy of two antidotes, edetate calcium disodium (CaNa $\left.{ }_{2} \mathrm{EDTA}\right)$ and dimercaptosuccinic acid (DMSA), for the treatment of lead poisoning in adults.

Methods: Thirty-seven patients with blood lead concentrations $>40 \mu \mathrm{g} / \mathrm{dL}$ and positive $\mathrm{CaNa}_{2} \mathrm{EDTA}$ lead mobilization were randomized to receive $1050 \mathrm{mg} / \mathrm{m}^{2} /$ day of oral DMSA $(n=21)$ or $500 \mathrm{mg} / \mathrm{m}^{2} /$ day of intravenous $\mathrm{CaNa}_{2}$ EDTA $(n=16)$ over two five-day courses separated by a 10-day rest period. Efficacy of treatment was evaluated by blood lead assays on the first day of the two courses and 14 days after the end of treatment and baseline $\mathrm{CaNa}_{2}$ EDTA lead mobilization test and 14 days after the end of treatment.

Results and conclusion: Both treatments significantly reduced the prevalence of clinical symptoms, blood lead levels and $\mathrm{CaNa}_{2}$ EDTA lead mobilization and were well tolerated. DMSA had a greater impact on reducing blood lead concentrations $(p=.005)$ and $\mathrm{CaNa}_{2}$ EDTA on lead mobilization $(p=.04)$. Comparison of equimolar doses showed that $\mathrm{CaNa}_{2}$ EDTA was more effective than DMSA $(p<.001)$.

\section{KEYWORDS}

$\mathrm{CaNa}_{2}$ EDTA; DMSA; succimer; lead; lead poisoning; edetate calcium disodium

\section{Introduction}

Although lead poisoning is one of the oldest and most extensively studied occupational diseases, many workers still remain exposed to lead in their workplace. Lead has deleterious effects on many major body systems, particularly on the nervous system and kidneys [1-3]. Chelation therapy has been used for more than half a century as a means of reducing the body lead burden. Intravenous edetate calcium disodium $\left(\mathrm{CaNa}_{2}\right.$ EDTA) has been the mainstay of treatment of lead poisoning and has been registered on the "WHO Model List of Essential Medicines" [4].

Several studies have demonstrated that the water-soluble derivative of dimercaprol, the meso form of dimercaptosuccinic acid (succimer, DMSA), is also a potent lead chelator [5]. The USA has even approved DMSA as the standard treatment for moderate lead poisoning and DMSA is also registered on the "WHO Model List of Essential Medicines" [4]. However, in other countries and particularly in France, $\mathrm{CaNa}_{2} \mathrm{EDTA}$ remains the agent most commonly used in adults, although DMSA can be administered orally and causes only minor side effects [5].

Clinical studies in children have suggested that $1050 \mathrm{mg} /$ $\mathrm{m}^{2} /$ day of DMSA is significantly more effective than 350 and $700 \mathrm{mg} / \mathrm{m}^{2} /$ day of DMSA and $1000 \mathrm{mg} / \mathrm{m}^{2} /$ day of $\mathrm{CaNa}_{2}$ EDTA, both in terms of enhancing lead excretion and reducing blood lead concentrations [6,7]. These studies also showed that the typical rebound increase in blood lead concentrations observed after chelation therapy is mostly complete one week after the last dose.

Four clinical studies have compared the efficacy of these two antidotes on daily urine and/or and blood lead levels in adults, but due to methodological limitations and inadequate dosing of chelating agents, no definitive conclusions can be drawn from these studies $[5,8-10]$. The main goals of the present study were to compare the safety and efficacy of oral DMSA and intravenous $\mathrm{CaNa}_{2}$ EDTA at usual daily doses for the treatment of lead poisoning in adults. Efficacy was evaluated not only in terms of the reduction of blood lead levels, but also clinically and using the $\mathrm{CaNa}_{2}$ EDTA lead mobilization test.

\section{Methods}

\section{Study design}

This was a prospective, open-label, single-center study of the efficacy and safety of $\mathrm{CaNa}_{2}$ EDTA and DMSA in the treatment of lead poisoning in adults. It was conducted at the Fernand Widal Hospital, Paris. The study protocol was approved by a research ethics committee. Written informed consent and patient assent were obtained from each patient.

\section{Patients}

All patients $\geq 18$ years with only occupational lead exposure, with blood lead levels $\geq 40 \mu \mathrm{g} / \mathrm{dL}$ and a positive $\mathrm{CaNa}_{2} \mathrm{EDTA}$ 
lead mobilization test $(>600 \mu \mathrm{g} / 5 \mathrm{~h}$ after administration of $500 \mathrm{mg} / \mathrm{m}^{2}$ ) [11] were eligible to participate in this trial. Patients were randomized to receive either $1050 \mathrm{mg} / \mathrm{m}^{2} /$ day (approximately $30 \mathrm{mg} / \mathrm{kg} /$ day) of oral DMSA $(n=21)$ or $500 \mathrm{mg} / \mathrm{m}^{2} /$ day (12-16 mg/kg/day) of intravenous $\mathrm{CaNa}_{2}$ EDTA $(n=16)$ over two five-day courses separated by a 10-day rest period.

Patients were excluded when they presented (a) known hypersensitivity to chelating agents; (b) a history or current physical findings of serious cardiovascular, renal, hepatic, endocrine, or metabolic conditions; (c) Glucose-6-phosphate dehydrogenase deficiency; (d) positive pregnancy test (e) or when they had used any chelating agents less than one month prior to enrolment.

\section{Chelating agent dose and formulation}

Each patient included in the study received either DMSA $\left(1050 \mathrm{mg} / \mathrm{m}^{2} /\right.$ day in three divided doses) or CaNa ${ }_{2}$ EDTA $\left(500 \mathrm{mg} / \mathrm{m}^{2} /\right.$ day as a one-hour infusion in $250 \mathrm{~mL}$ of $5 \%$ dextrose).

Treatment was initiated an average of 24 days after the baseline assessment and consisted of five-day courses in all groups. All but one patient received two courses with a 10day rest period between the two courses. The same chelating agent was administered for both courses. The dosage regimens used for the two agents were those usually recommended in France and used in our department for lead chelation in adults. The five-day courses and 10-day rest interval were based on toxicokinetic parameters: both chelating agents are mostly confined in extracellular fluids [12,13]; lead depletion of this reduced space is rapid and repeated administration of either DMSA or $\mathrm{CaNa}_{2}$ EDTA to lead poisoned patients consequently allows only low urinary excretion after a few days; a treatment-free interval is necessary to allow redistribution from bone.

The following investigations were performed in all patients on the first day of each course, on the last day of the second course and 14 days after the end of treatment: physical examination, blood lead assay, complete blood count, urine delta-aminolevulinic acid (ALA), blood zinc-protoporphyrin (ZPP), serum creatinine and uric acid, plasma alanine and aspartate aminotransferases (ALT and AST), gamma-glutamyl transpeptidase, bilirubin and serum electrolytes including calcium and magnesium. For the lead mobilization test, urinary lead excretion was determined on the urine produced $5 \mathrm{~h}$ after administration of $500 \mathrm{mg} / \mathrm{m}^{2}$ of $\mathrm{CaNa}_{2}$ EDTA [11]. Avoidance of occupational lead exposure was maintained for all patients from at least one day before the first dose of chelating agent until the day after the last evaluation, 14 days after the end of treatment.

\section{Analytical methods}

Lead assays were performed by electrothermal atomic absorption spectrometry (ETAAS) with $5100 \mathrm{PC}$ and SIMAA 6100 spectrometers (Perkin Elmer, Les Ulis, France) both using a Zeeman background correction $[25,26]$. The light source consisted of a hollow lead cathode lamp (analysis wavelength: $283.31 \mathrm{~nm}$ ). Furnaces with integrated platform were used.

\section{Blood}

Whole blood was diluted $1: 10$ in a $0.06 \mathrm{~g} / \mathrm{L}$ palladium nitrate and $0.125 \%$ Triton $\mathrm{X}-100^{\circledR}$ solution. Calibration was performed by the addition-calibration technique. Five internal quality controls were analyzed in each series: Seronorm ${ }^{\circledR}$ Whole Blood Level 1 (Sero, Norway) and Utak $^{\circledR}$ Lead levels 1-4 (Utak Laboratories, Valencia, CA). The limits of detection (LOD defined as three standard deviations (SD) from the blank) and quantitation (LOQ defined as 10 SD from the blank) were 0.8 and $2.8 \mu \mathrm{g} / \mathrm{L}$, respectively. The LOQ determined by the coefficient of variation (CV) method was $4 \mu \mathrm{g} / \mathrm{L}$ for a $20 \%$ CV. Reproducibility determined at four concentration levels $(35,51,86$ and $133 \mu \mathrm{g} / \mathrm{L}$, respectively) was 3.4, 3.1, 3.2 and $5.9 \%$, respectively. The laboratory successfully participated in the French national quality control and the TEQAS international inter-laboratory scheme organized by the University of Surrey (England).

\section{Urine}

Urine samples were diluted 1:5 (spontaneous lead) or 1:25 or 1:100 (lead mobilization test) prior to analysis. Calibration was performed by the standard addition technique applied to each sample. Palladium nitrate was used as matrix modifier. LOD and LOQ were 3.1 and $10 \mu \mathrm{g} / \mathrm{L}$, respectively. Seronorm ${ }^{\circledR}$ Urine levels 1 and 2 (Sero, Norway) were used as internal quality controls.

\section{Efficacy}

Efficacy was assessed in terms of: a) resolution of clinical signs or symptoms, b) changes in blood lead levels measured before the first dose of the first and second courses and 14 days after the end of treatmentand c) $\mathrm{CaNa}_{2}$ EDTA lead mobilization test at baseline and on day 14 post-treatment.

No $\mathrm{CaNa}_{2}$ EDTA lead mobilization test was performed before the end of treatment in order to avoid any interference in the DMSA group.

The efficacy of the two chelating agents was also compared on a molar basis (one mole of DMSA versus one mole of $\left.\mathrm{CaNa}_{2} \mathrm{EDTA}\right)$ : considering that the molecular weights of $\mathrm{CaNa}_{2}$ EDTA and DMSA are 374 and 182, respectively, the dosage regimens of $1050 \mathrm{mg} / \mathrm{m}^{2} /$ day of DMSA and $500 \mathrm{mg} /$ $\mathrm{m}^{2} /$ day of $\mathrm{CaNa}_{2}$ EDTA correspond to $5.76 \mathrm{mmol} / \mathrm{m}^{2} /$ day and $1.34 \mathrm{mmol} / \mathrm{m}^{2} /$ day, respectively.

\section{Safety}

Safety was assessed by the presence of any clinical or laboratory abnormalities. 
Table 1. Patient demographics and median baseline patient characteristics.

\begin{tabular}{|c|c|c|c|}
\hline Parameters & CaNa2EDTA $n=14$ & DMSA $n=20$ & $p$ Value \\
\hline Age $\left(\right.$ years) ${ }^{a}$ & $41 ; 9$ & $44 ; 13$ & .10 \\
\hline Males $(n(\%))$ & $14(100 \%)$ & $20(100 \%)$ & $>.99$ \\
\hline BMI $\left(\mathrm{kg} / \mathrm{m}^{2}\right)^{\mathrm{a}}$ & $28 ; 7$ & $26 ; 4$ & .12 \\
\hline Duration of exposure (years) ${ }^{a}$ & $17 ; 21$ & $9 ; 17$ & .17 \\
\hline Baseline blood $\mathrm{Pb}(\mu \mathrm{g} / \mathrm{dL})^{\mathrm{a}}$ & $52.7 ; 12,3$ & $58.2 ; 21.9$ & .12 \\
\hline \multicolumn{4}{|l|}{ Baseline $\mathrm{CaNa}_{2}$ EDTA lead mobilization test ${ }^{\mathrm{a}}$} \\
\hline$\mu \mathrm{g} / 5 \mathrm{~h}$ & $1225 ; 919$ & $1592 ; 1235$ & .29 \\
\hline$\mu \mathrm{g} / \mathrm{g}$ creatinine & $3601 ; 2200$ & $3918 ; 2801$ & .73 \\
\hline$\mu \mathrm{g} / 5 \mathrm{~h} / \mathrm{mg} \mathrm{CaNa}{ }_{2} \mathrm{EDTA}$ & $1.27 ; 0.84$ & $1.45 ; 1.31$ & .31 \\
\hline Initial symptoms $(n(\%))$ & $7(50 \%)$ & $16(80 \%)$ & .06 \\
\hline Asthenia & $2(14 \%)$ & $9(45 \%)$ & \\
\hline Abdominal pain & $2(14 \%)$ & $4(20 \%)$ & \\
\hline Constipation & $2(14 \%)$ & $3(15 \%)$ & \\
\hline Headache & $1(7 \%)$ & $5(5 \%)$ & \\
\hline Irritability & $1(7 \%)$ & $4(20 \%)$ & \\
\hline Memory and concentration difficulties & $3(21 \%)$ & $6(30 \%)$ & \\
\hline Insomnia & $1(7 \%)$ & $4(20 \%)$ & \\
\hline Libido disorders & $1(7 \%)$ & $2(10 \%)$ & \\
\hline Anemia & $2(14 \%)$ & $4(20 \%)$ & \\
\hline
\end{tabular}

${ }^{\mathrm{a}}$ Median; interquartile interval.

\section{Statistical analysis}

Statview statistical software (SAS Institute Inc., Cary, NC) was used to analyze data. Qualitative data in the two groups were compared by Chi-squared test or Fisher's exact test. Successive measurements of the same parameter in the same patient were compared using the non-parametric Wilcoxon signed-rank test. Intergroup comparisons used the MannWhitney test. The limit of significance accepted for all statistical tests was $\alpha=0.05$.

\section{Results}

\section{Patient characteristics}

Inclusion in the study was proposed to 60 male patients with blood lead levels $>40 \mu \mathrm{g} / \mathrm{dL}$ and a positive $\mathrm{CaNa}_{2}$ EDTA lead mobilization test. It was accepted by 37 who were randomly assigned to receive either $1050 \mathrm{mg} / \mathrm{m}^{2} /$ day of oral DMSA $(n=21)$ or $500 \mathrm{mg} / \mathrm{m}^{2} /$ day of intravenous $\mathrm{CaNa}_{2} \mathrm{EDTA}$ ( $n=16)$ over two five-day courses separated by a 10-day rest period. The other 23 patients systematically received $500 \mathrm{mg} /$ $\mathrm{m}^{2} /$ day of intravenous $\mathrm{CaNa}_{2}$ EDTA, the reference treatment for lead poisoning in adults in France during the period of this study. Three out of the 37 patients were subsequently excluded: two from the $\mathrm{CaNa}_{2} \mathrm{EDTA}$ group (one patient had received only one course of the chelating agent and the other patient did not perform the final evaluation tests) and one from the DMSA group, because complete avoidance of lead exposure was not obtained during treatment. Table 1 shows the initial characteristics of the two groups, which were not significantly different.

\section{Effects on clinical symptoms}

Sixteen (80\%) subjects in the DMSA group and seven (50\%) subjects in the $\mathrm{CaNa}_{2}$ EDTA group presented nonspecific symptoms compatible with lead poisoning, before inclusion in the trial. This difference was not statistically significant. Fourteen days after the end of treatment, eight patients in the DMSA group and two patients in the $\mathrm{CaNa}_{2}$ EDTA group
Table 2. Effects on clinical symptoms.

\begin{tabular}{|c|c|c|c|c|}
\hline \multirow[b]{2}{*}{ Symptoms } & \multicolumn{2}{|c|}{$\mathrm{CaNa}_{2} \mathrm{EDTA}$} & \multicolumn{2}{|c|}{ DMSA } \\
\hline & Before & After & Before & After \\
\hline Symptomatic patients $(n)$ & 7 & 5 & 16 & 13 \\
\hline Patients with asthenia $(n)$ & 2 & 2 & 9 & 5 \\
\hline Patients with abdominal pain $(n)$ & 2 & 1 & 4 & 0 \\
\hline Patients with constipation $(n)$ & 2 & 1 & 3 & 2 \\
\hline Patients with headache $(n)$ & 1 & 1 & 5 & 3 \\
\hline Patients with irritability $(n)$ & 1 & 1 & 4 & 3 \\
\hline $\begin{array}{l}\text { Patients with memory and } \\
\text { concentration difficulties }(n)\end{array}$ & 3 & 3 & 6 & 5 \\
\hline Patients with insomnia $(n)$ & 1 & 1 & 4 & 2 \\
\hline Patients with libido disorders ( $n$ ) & 1 & 1 & 2 & 2 \\
\hline Patients with anemia $(n)$ & 2 & 1 & 4 & 2 \\
\hline
\end{tabular}

reported some clinical improvement. In other words, chelation with one or the other chelating agent significantly reduced the prevalence of symptomatic patients $(p<.05)$; both treatments were associated with a decreased proportion of patients with clinical signs or symptoms, but this decrease was not statistically significant when each chelating agent was considered separately (Table 2).

\section{Effects on blood lead concentrations}

Blood lead concentrations decreased significantly in both groups between the first days of the two courses and between the first day of the second course and the day 14 after the end of treatment. The median decreases in blood lead levels were 24\% (IQR 16-25; $p<.05$ ) and 15\% (IQR 3-22; $p<.05$ ) in the $\mathrm{CaNa}_{2} \mathrm{EDTA}$ group and 39\% (IQR 32-50; $p<.05$ ) and 19\% (IQR 4-27; $p<.05$ ) in the DMSA group, respectively (Tables 3 and 4 and Figure 1). DMSA chelation was significantly more effective than $\mathrm{CaNa}_{2}$ EDTA chelation, globally $(p=.015)$ and during the first course $(p=.002)$, but not during the second course. However, it should be noted that, in this trial (and in all of the usually recommended therapeutic protocols), DMSA was used at much higher molar doses than $\mathrm{CaNa}_{2}$ EDTA. After adjustment for molar weight, $\mathrm{CaNa}_{2}$ EDTA was found to be a significantly superior chelating agent to DMSA, globally $(p<.0001)$ and during the first course $(p<.001)$. 
Table 3. Time-course of blood lead levels during chelation therapy.

\begin{tabular}{|c|c|c|c|c|}
\hline Blood lead levels & Total $n=34$ & $\mathrm{CaNa}_{2}$ EDTA $n=14$ & DMSA $n=20$ & $p$ Value \\
\hline First day of $1^{\text {st }}$ course $(\mu \mathrm{g} / \mathrm{dL})^{\mathrm{a}}$ & $55.4 ; 17.4$ & $52.7 ; 12.3$ & $58.2 ; 21.9$ & .12 \\
\hline First day of $2^{\text {nd }}$ course $(\mu \mathrm{g} / \mathrm{dL})^{\mathrm{a}}$ & $36.5 ; 15.8$ & $40.1 ; 14.4$ & $33.4 ; 13.7$ & .29 \\
\hline Day 14 after the end of treatment $(\mu \mathrm{g} / \mathrm{dL})^{\mathrm{a}}$ & $31.3 ; 14.3$ & $31.4 ; 19.4$ & $30.8 ; 11.6$ & .49 \\
\hline
\end{tabular}

${ }^{a}$ Median; interquartile interval.

Table 4. Pre- to post-treatment decrease of blood lead levels.

\begin{tabular}{|c|c|c|c|}
\hline Decrease of blood lead levels & $\mathrm{CaNa}_{2} \mathrm{EDTA} n=14$ & DMSA $n=20$ & $p$ Value \\
\hline Absolute concentration $(\mu \mathrm{g} / \mathrm{dL})^{a}$ & $18.4 ; 10.0^{*}$ & $27.9 ; 12.9^{*}$ & .0054 \\
\hline Relative decrease $(\%)^{a}$ & $38 ; 13 *$ & $51 ; 20 *$ & .015 \\
\hline After adjustment for molar weight ( $\mu \mathrm{g} / \mathrm{dL} /$ mole of chelating agent) ${ }^{\mathrm{a}}$ & $13.7 ; 7.5^{*}$ & $4.9 ; 2.3^{*}$ & $<.0001$ \\
\hline
\end{tabular}

${ }^{a}$ median; interquartile interval. ${ }^{*} p<0.05$ for the difference between blood lead levels before and after treatment in each group

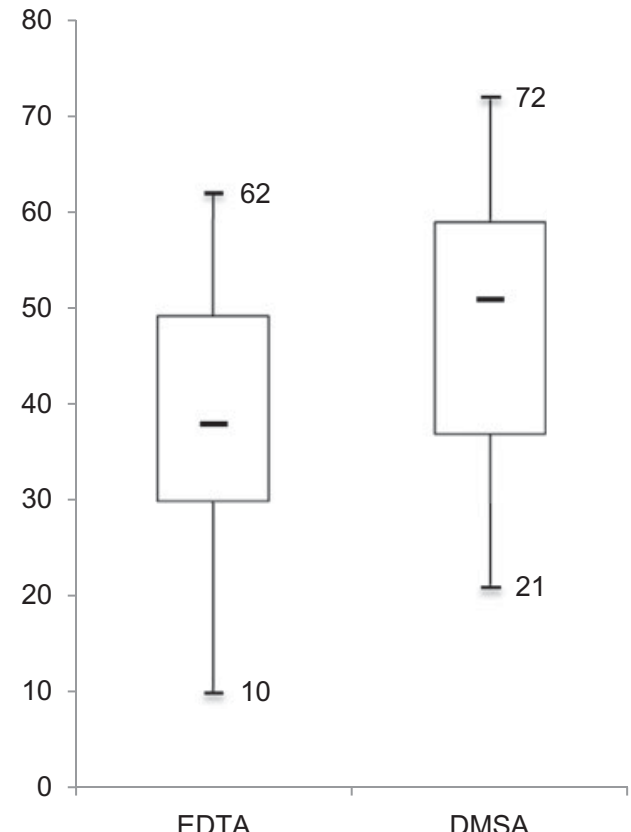

Figure 1. Pre- to post-treatment decrease of blood lead concentrations in each group (\%).

\section{Effects on lead mobilization test}

Evaluation of the efficacy of the two treatments based on the lead mobilization test provided globally similar results to those obtained for blood lead levels. Regardless of the expression of the results of the mobilization test $(\mu \mathrm{g} / 5 \mathrm{~h}$, $\mu \mathrm{g} / \mathrm{g}$ creatinine or $\mu \mathrm{g} / 5 \mathrm{~h} / \mathrm{mg} \mathrm{CaNa}_{2}$ EDTA), induced lead excretion was significantly decreased in both groups between the first day of treatment and the day 14 after the end of treatment, in both the DMSA and $\mathrm{CaNa}_{2}$ EDTA groups (Table 5). The medians of these decreases were $65-67 \%$ $(p<.05)$ in the $\mathrm{CaNa}_{2}$ EDTA group and $78 \%$ in the DMSA group. The difference between the two treatments was at the limit of statistical significance. However, after adjustment for the molar weights of the two compounds, $\mathrm{CaNa}_{2} \mathrm{EDTA}$ was significantly superior to DMSA at equimolar doses ( $p<.001$; Table 6).

\section{Safety}

Both treatments were generally well tolerated by the patients. One patient in the DMSA group complained of palpitations, sweating, unpleasant smell of urine and decreased libido during the first three days of treatment. No clinical complaints were reported in the $\mathrm{CaNa}_{2} \mathrm{EDTA}$ group.

Laboratory abnormalities were noted in several patients during treatment.

One patient in the DMSA group presented elevation of serum creatinine during the second course (from 100 to $127 \mu \mathrm{mol} / \mathrm{L})$ that returned to normal after treatment ( $98 \mu \mathrm{mol} / \mathrm{L}$ on day 14 after treatment).

Transient elevations of hepatic enzymes (culminating at less than three times the upper limit of normal) were observed in two patients in the $\mathrm{CaNa}_{2}$ EDTA group and in five patients in the DMSA group. An alternative explanation for elevated hepatic enzyme activity could be proposed in the two patients receiving $\mathrm{CaNa}_{2}$ EDTA (alcohol consumption in one case and acute lead poisoning in the other case). Hepatic enzymes spontaneously returned to normal in less than one month in all cases.

Numerous studies have demonstrated that DMSA treatment does not induce depletion of essential trace elements [14]. $\mathrm{CaNa}_{2}$ EDTA increases urinary elimination of various essential trace elements (especially zinc), but depletion is unlikely after only two consecutive five-day courses. On the other hand, zinc concentrations in plasma or urine spot samples are poor indicators of internal zinc concentrations $[15,16]$. For these reasons, zinc assays were not performed in this study.

\section{Discussion}

Only a few published clinical studies have compared DMSA and $\mathrm{CaNa}_{2}$ EDTA chelation for the treatment of lead poisoning.

In 1988, Graziano et al. [2] treated 21 children, aged 2-7 years with initial blood lead levels between 31 and $49 \mu \mathrm{g} / \mathrm{dL}$, with either DMSA $\left(350,700\right.$ or $1050 \mathrm{mg} / \mathrm{m}^{2} /$ day in three divided doses), or $\mathrm{CaNa}_{2}$ EDTA $\left(1000 \mathrm{mg} / \mathrm{m}^{2} /\right.$ day in two separate infusions) for five days. They showed that the decrease in blood lead levels between the start and the end of treatment was more pronounced with DMSA $1050 \mathrm{mg} / \mathrm{m}^{2} /$ day than with the other three regimens. They observed a rebound increase of blood lead levels after the end of treatment in all groups, but this rebound was less pronounced with DMSA than with $\mathrm{CaNa}_{2}$ EDTA. In a subsequent study, Graziano et al. 
Table 5. Pre- and post-treatment lead mobilization test results.

\begin{tabular}{|c|c|c|c|c|}
\hline Lead mobilization test & Total $n=34$ & $\mathrm{CaNa}_{2} \mathrm{EDTA}_{n}=14$ & DMSA $n=20$ & $p$ Value \\
\hline \multicolumn{5}{|l|}{ Baseline } \\
\hline$(\mu \mathrm{g} / 5 \text { hours })^{\mathrm{a}}$ & 1389; 1092 & $1225 ; 919$ & 1592; 1235 & .29 \\
\hline$(\mu \mathrm{g} / \mathrm{g} \text { creatinine })^{\mathrm{a}}$ & $3746 ; 2609$ & $3601 ; 2200$ & $3918 ; 2801$ & .73 \\
\hline$\left(\mu \mathrm{g} / 5 \text { hour } / \mathrm{mg} \mathrm{CaNa}{ }_{2} \mathrm{EDTA}\right)^{\mathrm{a}}$ & $1.42 ; 1,20$ & $1.27 ; 0,84$ & $1.45 ; 1.31$ & .31 \\
\hline \multicolumn{5}{|c|}{ Fourteen days after the end of treatment } \\
\hline$(\mu \mathrm{g} / 5 \text { hours })^{\mathrm{a}}$ & 307; 185 & $331 ; 316$ & 307; 185 & .50 \\
\hline$\left(\mu \mathrm{g} / \mathrm{g}{\text { creatinine })^{\mathrm{a}}}\right.$ & $944 ; 851$ & $1033 ; 750$ & $796 ; 874$ & .22 \\
\hline$\left(\mu \mathrm{g} / 5 \text { hour } / \mathrm{mg} \mathrm{CaNa}{ }_{2} \text { EDTA }\right)^{\mathrm{a}}$ & $0.30 ; 0.21$ & $0.31 ; 0.20$ & $0.29 ; 0,22$ & .82 \\
\hline
\end{tabular}

${ }^{a}$ Median; interquartile interval.

Table 6. Pre- to post-treatment decrease of lead mobilization test.

\begin{tabular}{|c|c|c|c|}
\hline Decrease of lead mobilization test & $\mathrm{CaNa}_{2}$ EDTA $n=14$ & DMSA $n=20$ & $p$ Value \\
\hline Absolute lead excretion ( $\mu \mathrm{g} / \mathrm{g}$ of creatinine) ${ }^{\mathrm{a}}$ & $2457 ; 1392^{*}$ & $2452 ; 2542^{*}$ & .55 \\
\hline Relative decrease (\%) ${ }^{\mathrm{a}}$ & $65 ; 13^{*}$ & $78 ; 11^{*}$ & .042 \\
\hline After adjustment for molar weight $(\mu \mathrm{g} / \mathrm{dL} / \mathrm{molar} \text { weight of chelator })^{\mathrm{a}}$ & 183.3; $103.8^{*}$ & $42.6 ; 44,1^{*}$ & .0002 \\
\hline
\end{tabular}

${ }^{a}$ Median; interquartile interval. ${ }^{*} p<0.05$ for the difference between lead mobilization tests before and after treatment in each group

[7] compared DMSA $\left(1050 \mathrm{mg} / \mathrm{m}^{2} /\right.$ day for five days followed by 700,350 or $0 \mathrm{mg} / \mathrm{m}^{2} /$ day for 14 days) with $\mathrm{CaNa}_{2}$ EDTA $\left(1000 \mathrm{mg} / \mathrm{m}^{2} /\right.$ day for five days) in 23 children aged $1-10$ years with initial blood lead levels between 50 and $69 \mu \mathrm{g} / \mathrm{dL}$. They again showed that the decrease in blood lead levels between the first and fifth days of treatment was significantly greater with DMSA than with $\mathrm{CaNa}_{2}$ EDTA; a rebound of blood lead levels was also observed in all groups after the fifth day of treatment, but was less pronounced in children receiving lower doses of DMSA. However, they present a number of severe flaws, particularly the very small sample sizes in each group and the parameter used to evaluate the efficacy of treatment, namely the decrease in blood lead levels between the first and last days of treatment, was inappropriate, as circulating lead during treatment is present in both free and chelated forms and redistribution from the bone pool is observed after completion of chelation, which explains the rebound of blood lead levels. As the blood lead level is used as a marker of the lead dose in the body, it must only be measured after completion of lead redistribution, i.e., not earlier than 10-15 days after the last administration of chelating agent.

Clinical studies comparing the two chelating agents for the treatment of lead poisoning have also been conducted in adults [5,8-10], but all published trials present major methodological flaws (very small study groups, unverified comparability of treated groups, comparison of blood (and/or urine) lead levels at toxicokinetically inappropriate times (see above), use of 24-h lead excretion for evaluation of efficacy with a high risk of incomplete sampling, variable dose regimens of chelating agents, etc.). Treatment groups were not randomized in any of the published studies in children or adults.

The present study is the first prospective study with a rigorous methodology to compare the DMSA and $\mathrm{CaNa}_{2}$ EDTA regimens generally used in France for the treatment of lead poisoning in adults. The efficacy of the chelating agents was evaluated on the basis of both clinical signs, symptoms and indicators of body lead burden (namely, variations of both blood lead levels and induced lead excretion).
Both indicators were measured at appropriate times to accurately reflect body lead burden.

All clinical and laboratory parameters were improved after both chelating treatments. Due to the subjective nature of all clinical signs and symptoms, a direct effect of the chelating agents cannot be distinguished from a possible placebo effect of treatment. However, resolution of all laboratory parameters demonstrated the efficacy of the two chelating regimens tested. Globally, the DMSA regimen $\left(1050 \mathrm{mg} / \mathrm{m}^{2} /\right.$ day, orally, in three divided doses) was more effective than the $\mathrm{CaNa}_{2}$ EDTA regimen $\left(500 \mathrm{mg} / \mathrm{m}^{2} /\right.$ day as a one-hour infusion) to decrease both blood lead levels and induced lead excretion. However, after adjustment for the molar weights of the two chelating agents, $\mathrm{CaNa}_{2} \mathrm{EDTA}$ was significantly superior to DMSA at equimolar doses. EDTA was administered daily to patients in our department. However, when DMSA is administered on an outpatient basis, there is no way of ensuring that all doses of DMSA were taken by the patients. Nevertheless, it should be noted that: a) treatment adherence can be expected to be good in these highly motivated volunteers, b) in our study, DMSA had a greater impact on reducing blood lead levels and $\mathrm{CaNa}_{2}$ EDTA mobilization compared to the EDTA regimen, which suggests good treatment adherence among DMSA-treated patients.

In this study, both DMSA and $\mathrm{CaNa}_{2}$ EDTA were generally well tolerated, which is consistent with previous publications on both chelating agents. Adverse effects of DMSA are uncommon and generally minor (mild and transient elevation of hepatic enzymes is the most common adverse effect) $[6,7,13,17-24]$. The main disadvantage of DMSA is probably the unpleasant odor it gives to excreta (3M Pharmaceuticals, Lake Forest, IL) [25]. This effect was reported by only one patient in our series, but it was one of the reasons given by patients to explain their decision not to participate. Adverse effects of $\mathrm{CaNa}_{2} \mathrm{EDTA}$ are also rare and mostly related to incorrect dosage [13,26-30].

Although this study is the largest study ever published on this topic, its main limitation is the small number of subjects included, as inclusion of new subjects was unexpectedly difficult. The information given to potential participants prior to 
inclusion had a marked dissuasive effect: patients were not afraid by the content of the information provided, but by the principles of informed consent and randomized treatment allocation; they were also reluctant about the unpleasant odor of excreta. Finally, only $62 \%$ of patients invited to participate provided their consent.

The major strength of our study concerns its methodology. To our knowledge, this is the first open-label therapeutic trial performed on lead poisoning. No previous studies have included patients providing their informed consent with randomized treatment allocation. Several published studies even failed to verify the comparability of treatment groups. The main tools used for evaluation of treatment efficacy in the present study were also much more appropriate than those used in previous studies: decrease in blood lead levels and induced lead excretion between the start of treatment and 10-15 days after the end of treatment, instead of decrease in blood lead levels between the first and last day of treatment (see above) or total urinary lead excretion during treatment (with the associated high risk of incomplete sampling).

DMSA allows outpatient treatment of lead poisoning and could constitute an alternative to $\mathrm{CaNa}_{2}$ EDTA. However, prevention is the mainstay of treatment and the most effective measure consists of removal of the lead risk from the workplace. Working conditions of poisoned workers should be investigated and improved.

\section{Conclusion}

This is the first open-label therapeutic trial comparing fiveday chelation with DMSA $\left(1050 \mathrm{mg} / \mathrm{m}^{2}\right.$ daily in three divided doses) or $\mathrm{CaNa}_{2}$ EDTA ( $500 \mathrm{mg} / \mathrm{m}^{2}$ as a daily one-hour infusion) for the treatment of lead poisoning in adults. Patients in all groups reported a certain degree of improvement of clinical symptoms/signs. Both treatments significantly decreased blood lead levels and induced lead excretion. Both were well tolerated. With the regimens tested, DMSA was slightly, but significantly more effective than $\mathrm{CaNa}_{2}$ EDTA (however, when comparing equimolar doses, $\mathrm{CaNa}_{2}$ EDTA was more effective than DMSA). $\mathrm{CaNa}_{2}$ EDTA chelation is more invasive, as it requires daily intravenous infusions. However, in the population of workers occupationally exposed to lead, treatment adherence is generally much better with $\mathrm{CaNa}_{2}$ EDTA because parenteral treatment comprises closer medical surveillance.

In conclusion, both treatments can be used when chelation is indicated. The chelating agent must be selected in collaboration with the patient, after providing information on the efficacy and safety of the two drugs, as well as the constraints related to the two treatments.

\section{Acknowledgements}

We thank all those patients who volunteered to participate in this study. DMSA was supplied by Serb Laboratory (Paris, France).

\section{Disclosure statement}

No potential conflict of interest was reported by the authors.

\section{References}

[1] ASTDR. Toxicological profile for lead. Atlanta: Agency for toxic substances and disease registry; 2007.

[2] EFSA panel on contaminants in the food chain (CONTAM). scientific opinion on lead in food. EFSA Journal. 2010;8:1570.

[3] NTP. Monograph on health effects of low-level lead evaluation. U.S.: Department of Health and Human Services, National toxicology program; 2012.

[4] WHO. WHO model lists of essential medicines. Geneva: World Health Organization; 2017.

[5] Bradberry S, Vale A. Dimercaptosuccinic acid (succimer; DMSA) in inorganic lead poisoning. Clin Toxicol. 2009;47:617-631.

[6] Graziano JH, Lolacono NJ, Meyer P. Dose-response study of oral 2,3-dimercaptosuccinic acid in children with elevated blood lead concentrations. J Pediatr. 1988;113:751-757.

[7] Graziano JH, Lolacono NJ, Moulton T, et al. Controlled study of meso-2,3-dimercaptosuccinic acid for the management of childhood lead intoxication. J Pediatr. 1992;120:133-139.

[8] Wang SC, Ting KS, Wu CC. Chelating therapy with Na-DMS in occupational lead and mercury intoxications. Chin Med J. 1965;84:437-439.

[9] Friedheim E, Graziano JH, Popovac D, et al. Treatment of lead poisoning by 2,3-dimercaptosuccinic acid. Lancet. 1978;2: 1234-1236.

[10] Lee BK, Schwartz BS, Stewart W, et al. Provocative chelation with DMSA and EDTA: evidence for differential access to lead storage sites. Occup Environ Med. 1995;52:13-19.

[11] Garnier R, Fournier E, L'épreuve de plomburie provoquée par I'EDTANa2Ca: validation d'un test court (5 heures) [The leadurie test provoked by the EDTANa2Ca: validation of a short test (5 hours)]. Paris: Université Paris Diderot; 1986. French.

[12] Liang YY, Marlowe C, Waddell WJ. Disposition of [14C]dimercaptosuccinic acid in mice. Fundam Appl Toxicol. 1986;6:532-540.

[13] Bradberry S, Vale A. A comparison of sodium calcium edetate (edetate calcium disodium) and succimer (DMSA) in the treatment of inorganic lead poisoning. Clin Toxicol. 2009;47:841-858.

[14] Fournier L, Thomas G, Garnier R, et al. 2,3-dimercaptosuccinic acid treatment of heavy metal poisoning in humans. Med Toxicol Adverse Drug Exp. 1988;3:499-504.

[15] Fischer Walker CL, Black RE. Functional indicators for assessing zinc deficiency. Food Nutr Bull. 2007;28:S454-S479.

[16] Hess SY, Peerson JM, King JC, et al. Use of serum zinc concentration as an indicator of population zinc status. Food Nutr Bull. 2007;28:S403-S429.

[17] Graziano JH, Siris ES, Lolacono N, et al. 2,3-dimercaptosuccinic acid as an antidote for lead intoxication. Clin Pharmacol Ther. 1985;37:431-438.

[18] Bradberry S, Sheehan T, Vale A. Use of oral dimercaptosuccinic acid (succimer) in adult patients with inorganic lead poisoning. QJM. 2009;102:721-732.

[19] Mann KV, Travers JD. Succimer, an oral lead chelator. Clin Pharm. 1991;10:914-922.

[20] Liebelt EL, Shannon M, Graef JW. Efficacy of oral meso-2,3-dimercaptosuccinic acid therapy for low-level childhood plumbism. J Pediatr. 1994;124:313-317.

[21] Chisolm JJ Jr. Safety and efficacy of meso-2,3-dimercaptosuccinic acid (DMSA) in children with elevated blood lead concentrations. J Toxicol Clin Toxicol. 2000;38:365-375.

[22] Group TT. Safety and efficacy of succimer in toddlers with blood lead levels of $20-44 \mathrm{microg} / \mathrm{dL}$. Treatment of lead-exposed children (TLC) trial group. Pediatr Res. 2000;48:593-599.

[23] Farrar HC, McLeane LR, Wallace $M$, et al. A comparison of two dosing regimens of succimer in children with chronic lead poisoning. J Clin Pharmacol. 1999;39:180-183. 
[24] O'Connor ME, Rich D. Children with moderately elevated lead levels: is chelation with DMSA helpful? Clin Pediatr. 1999;38: 325-331.

[25] Volans GN, Karalliedde L, Wiseman HM. Review of Succimer for Treatment of Lead Poisoning. Geneva: World Health Organization; 2010.

[26] Vogt W, Cottier H. [Necrotizing nephrosis after treatment of a subacute- chronic lead poisoning with high dosed versenate]. Schweiz Med Wochenschr. 1957;87:665-667. German.

[27] Wedeen RP, Batuman V, Landy E. The safety of the EDTA leadmobilization test. Environ Res. 1983;30:58-62.
[28] Moel DI, Kumar K. Reversible nephrotoxic reactions to a combined 2,3-dimercapto-1-propanol and calcium disodium ethylenediaminetetraacetic acid regimen in asymptomatic children with elevated blood lead levels. Pediatrics. 1982;70:259-262.

[29] Yver L, Marechaud R, Picaud D, et al. [Acute renal failure in the course of occupational lead intoxication. Chelation therapy responsability (author's transl)]. Nouv Presse Med. 1978;7: 1541-1543. French.

[30] Araki S, Aono H, Murata K. Mobilisation of heavy metals into the urine by CaEDTA: relation to erythrocyte and plasma concentrations and exposure indicators. Br J Ind Med. 1986;43:636-641. 